\title{
Sino-Africa Cooperation under the Influence of the Belt and Road Initiative
}

\author{
Xiaoyang Guo ${ }^{1, \dagger}$, Zixin $\mathrm{Jia}^{2, \dagger}$, Yaohua $\mathrm{Liu}^{3,{ }^{*}, \dagger}$ \\ 1Department of Information Management, Jiangxi University of Finance and Economics, \\ NanChang, 330013, China \\ ${ }^{2}$ Department of Business English, University of International Business and Economics, Beijing, \\ 100029, China \\ ${ }^{3}$ College of Agricultural and Environmental Sciences, University of California, Davis, Davis, 95616, \\ the United States \\ *Corresponding author. Email: wuhliu@ucdavis.edu \\ tThese authors contributed equally
}

\begin{abstract}
The Belt and Road initiative is one of the most important parts of China's overseas business strategy. The African region is also included in the Belt and Road initiative. This paper aims to study the important position of Africa in the Belt and Road strategy through the economic cooperation and project construction between China and Africa under the framework of the Belt and Road. China-Africa cooperation has a long history. Africa has many limitations in infrastructure but rich in natural resources. China's strong manufacturing system can both make full use of natural resources from Africa and invest in African infrastructure. In recent years, China-Africa cooperation has been deepening and expanding in scale. The Belt and Road Initiative has brought win-win results to China and Africa. As China consumes excess capacity and realizes the goal of Chinese manufacturing going global, African countries have achieved economic development, improved infrastructure construction and stride toward industrialization.
\end{abstract}

Keywords: The Belt and Road Initiative; Sino-Africa cooperation; Win-win cooperation.

\section{Introduction}

The Belt and Road initiative is short for the Silk Road Economic Belt and the 21st Century Maritime Silk Road, which were proposed by Chinese President Xi Jinping in September and October 2013 respectively. Relying on the existing bilateral and multilateral mechanisms between China and relevant countries and the existing and effective regional cooperation platforms, the Belt and Road aims to borrow the historical symbol of the ancient Silk Road, hold the banner of peaceful development, and actively develop economic cooperative partnerships with countries along the routes. China appeals to other countries to jointly build a community of shared interests, shared future and shared responsibilities featuring political mutual trust, economic integration, and cultural inclusiveness.

Sino-African relations date back to the Ming Dynasty when fleets reached East Africa. Formal diplomatic relations between China and Africa were established at the beginning of the founding of new China, with the first wave of African countries' independence. The Forum on China-Africa Cooperation (FOCAC), a landmark in the history of the Sino-Africa relationship was created in 2000 as a platform for collective consultation and dialogue and a cooperation mechanism. The FOCAC and its activities are closely aligned with China's Africa policy which was formulated in 2006 with the broad objective of enhancing all-round cooperation between China and Africa in such key areas as political, economic, education, science, culture, health, peace, and security. The emergence in September 2013 of the Chinese "Belt and Road Initiative" (BRI) was an additional chapter in history. Economic ties between China and Africa have expanded beyond extractive trade and investment to include communications, infrastructure, manufacturing, finance, media, and agriculture. Meanwhile, China and Africa have also cooperated on international security and peace issues. 
Volume 16 (2021)

This paper intends to analyze the development of infrastructure, comparative advantages and cooperation with China in African countries, and study how China and Africa achieve a win-win situation through the Belt and Road, as well as the opportunities and challenges facing China.

\section{Related Research}

Firstly, the scholars gave us a comprehensive understanding of how BRI implements in Africa and why China and Africa are so interested in such projects, the following studies give us a clear gist and a background of the history of Sino-Africa cooperation, the development of the Belt and Road Initiative in Africa and etc.

Breuer came up with a comprehensive analysis of how the One Belt One Road initiative impacts Africa and improves the international influence of China. Breuer firstly introduced the historical background of the investment and cooperation between Africa and China, which gave us a broad view of Sino-Africa relations. Secondly, he emphasized the infrastructure in the project. He noted the "Angola Model" to show how China invested in Africa and got related benefits. Then, he used a lot of examples of successes of OBOR in African countries to show the effectiveness. Next, he used more practical examples and data to tell us the interest of China and how it impacts Africa. Finally, he gave a positive perspective of OBOR in Africa and mentioned some of his own opinions [1]. Abegunrin and Manyeruke reviewed the historical background of cooperation between China and Africa, and concluded the value of One Belt One Road in Africa. Through introducing the background and aims of OBOR, the authors let us know the strategies of China to improve its politics, diplomacy and soft power. Then, to be more specific, the authors emphasized geopolitics, security, economic and implication of OBOR initiatives and used quantitative data to show the impacts of OBOR. In conclusion, the authors state some impediments to the progress of OBOR in Africa but they still hold an optimistic attitude of the future of OBOR in Africa [2]. Chen reviews the development history of the Belt and Road and China's strategic decisions, and studies the impact of the Belt and Road on Africa through detailed charts and data. In conclusion, this study argues that Chinese investments in Africa in the past 10 years have increased rapidly, however it has not been proportional to the increase in pace and volume of Chinese outward investment. As far as foreign investment is concerned, African states should take action in order to grasp the opportunities to benefit from China's Belt and Road Initiative. Improving Sino-African BITs is a necessary and effective step to take, among others [3].

Next, the following studies emphasize trade and infrastructure investment because they are the major parts in the cooperation. In the following paragraphs, Chinese firms invest in Africa and how the BRI plays its role in Africa are the main topics. Tatiana paid special attention to Africa's role in the Belt and Road initiative. This new route can not only reduce trade barriers and reorient trade, but also address the challenges and threats in the African region. The Belt and Road initiative has financed Africa's development, laying the foundation for future industrial development through the construction of mega projects and the establishment of industrial parks. The completion of these projects has created new impetus and stimulated economic development in Africa, promoted partnership among countries and strengthened the integration process on the African continent [4]. Mukwaya and Mold researched the effect of the People's Republic of China's Belt and Road initiative strategy on trade and welfare in Eastern Africa. The study analyzed the impact of the establishment of the BRI through the Global Trade Analysis Project (GTAP) computable general equilibrium (CGE) model and the latest GTAP 10 database. Mukwaya and Mold focused on one of the BRI projects in East Africa, the standard gauge railway. The standard gauge railway was thought to reduce transport cost in the region. Reducing the export and import trade could lead to increasing the GDP growth. It could contribute to regional welfare and promote intra-regional trade [5]. The author examines the most iconic OBOR project in Kenya, the Standard Gauge Railway (SGR) from the port of Mombasa to Nairobi. The construction of the Mombasa-Nairobi Railway has made many achievements, but also faces many challenges. With the construction of SGR, the employment problem of many local 
people was solved, the production of building materials was accelerated, and the development of other industries was promoted. Improving the efficiency of passenger and freight transport between Mombasa and Nairobi has had a positive impact on the transformation and upgrading of Kenya's economic development. SGR expanded its shipping business to break even. Of course, Kenya also faces a serious debt burden and pressure for sustainable development [6]. Calderón made a comprehensive assessment of the impact of infrastructure construction on economic growth in African countries. Based on a large amount of data, data models and econometric techniques, the research showed that infrastructure stock and service quality have a positive impact on economic growth. Infrastructure promotes productivity growth. By building infrastructure on a large scale, African countries are more likely to reap greater benefits, especially in communications and transport [7].

Finally, the challenges and opportunities in the project also attract scholars' attention. Africa has a large market and a lot of potential cooperating opportunity; however, a lot of western countries have existing benefits in Africa, involvement of China in Africa is a big challenge for them. Plus, the political situations in many African countries are unstable, the future of the BRI is still obscure and unpredictable. Mwatela and Changfeng put a review of China's strategy as an initiative, and illustrate the status of "One Belt, One Road" (OBOR) in Africa. The researchers researched project impact in Kenya, Egypt, Djibouti and analysed opportunities and challenges offered by OBOR in Africa. They concluded that although OBOR in Africa does not mirror the optimism that Sino-African relationship has attracted in the recent past. However, the opportunity for further cooperation is still there. PRC can seize the opportunity presented by OBOR to streamline its foreign direct investment in the continent to leave a lasting footprint. Successful implementation will result in firmly entrenching China as a true friend for Africa. China has global ambitions, while Africa is in dire need of capital for infrastructural development, and OBOR offers the best platform to pursue this [8]. Abdi and Ehizuelen mainly want to see the possibilities of expanding the One Belt One Road initiative in Africa and they used a number of examples and data to show the opportunities and challenges. Firstly, they introduced the economic motivator of OBOR initiative and then, they cited detailed economic data of several countries and regions to show the economic impact of OBOR. Secondly, they claimed why African countries are so important in OBOR initiative and the reasons why China should expand OBOR in Africa by evidence. Finally, they mentioned a lot of existing and potential opportunities and challenges of expanding OBOR in Africa and provided several practical suggestions to navigate China out of such challenges [9]. Zhou analyzes the profits that China benefits domestically and internationally from the cooperation and then points out the problems and obstacles lying ahead and proposes some solutions. The author concluded that Africa plays a crucial part in the development of OBOR. China needs to strengthen its communication and link with Africa by making full use of opportunities like the Forum on China-Africa Cooperation, for there lacks enough exchange of information, such as communication between Chinese banks and African governments. Since China's enterprises are the main force to move forward OBOR, China should provide more platforms and opportunities for them by building some connections between the enterprises and local governments [10]. Dollar examines the implementation of BRI infrastructure projects in Africa in light of available information and concludes that African experiences with the BRI are quite heterogeneous. The author claims that it is hard to make simple generalizations about BRI in Africa. It would be wise for Western countries to tone down their rhetoric on BRI, as many of the projects will probably work out well. It would help if Western countries provided more support to the International Monetary Fund to help countries manage their borrowing and to the World Bank to provide more infrastructure financing that increased options for the developing countries of Africa [11]. 


\section{The economic condition of Africa and Sino-Africa economic cooperation}

\subsection{Current situation of Infrastructure Construction in Africa}

Africa lags badly behind the rest of the world in infrastructure development. According to the business Environment Index of infrastructure Markets in sub-Saharan Africa released by BMI at the end of September 2013, the business environment index of infrastructure markets in Sub-Saharan Africa is relatively low, with an average of 44.5 points in the comprehensive evaluation region and only 53.8 points in Ghana [12]. In addition, the high business environment index of the infrastructure market is mostly found in southern African countries, while the low index is found in eastern African countries.

On the one hand, from the perspective of the development of infrastructure construction in various fields in Africa, there is a serious shortage of infrastructure construction in Africa. First of all, in terms of transportation, the African continent currently accounts for $20 \%$ of the world's total land area [14], but its total railway length accounts for only 5\% of the world's total railway length, and 13 out of 54 African countries have no railway [15]. The density of ordinary roads and expressways in Africa is one-fourth and one-tenth of the world average, respectively. The density of railways and highways in BRICS countries (Brazil, Russia, India and China) is 4.9 times and 2.3 times higher than that in Africa, respectively [15]. According to "Transport Prices and Costs in Africa", transport costs on the Continent are $63 \%$ higher than in developed countries, accounting for 30-50\% of total exports, and as much as $75 \%$ in 16 landlocked countries (Zimbabwe, South Sudan, Mali, Niger, etc.) [13].

Second, electricity. According to a report by Standard Chartered Bank Group, about $50 \%$ of countries on the African continent are seriously short of electricity, and electricity prices are 2-3 times higher than those in Asia. The BRICS has 2.4 times more electricity than Africa's 54 countries [16]. Third, water resources. According to the African Development Bank, $40 \%$ of Africans lack safe drinking water. On March 3, 2014, a water resources organization said millions of people in southern Africa still lack access to clean drinking water and public sanitation facilities such as latrines. Fourthly, in terms of communications, Africa has the lowest telephone and Internet penetration in the world. On May 5, 2014, the International Telecommunication Union (ITU) released the communication Industry development Forecast for 2014. According to the forecast, although the fixed broadband users in Africa maintained a double-digit growth momentum from 2010 to 2013, they accounted for less than $0.5 \%$ of the global total, mobile broadband penetration rate in Africa was $19 \%$, and Internet connection was only 10\% [17]. The infrastructure situation of Africa and Proportion of industry project as shown in the figures below. Project number and investment surged in 2018. Energy and power, transportation industry and real estate industry account for the largest share, more than $70 \%$.

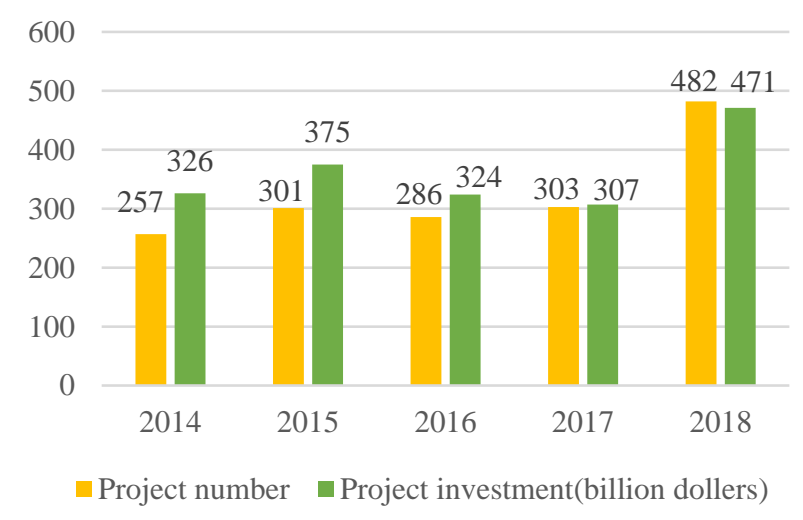

Figure 1. The infrastructure situation of Africa 


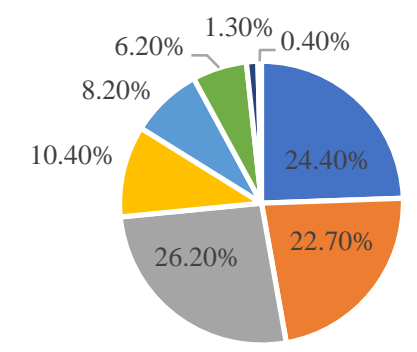

$$
\begin{aligned}
& \text { - Energy and power } \quad \text { - Transportation industry } \\
& \text { - The real estate industry } \\
& \text { - Shipping and ports } \\
& \text { - Oil-gas industry } \quad \text { - Water conservation } \quad \text { - Healthcare industry }
\end{aligned}
$$

Figure 2. Proportion of industry project

\subsection{The Comparative Advantages of African Countries}

Africa has its own unique advantages. Africa has abundant natural resources, and there is still a large amount of arable land that has not been effectively exploited and utilized. Several African countries have coal, oil, natural gas and uranium resources and are suppliers to world energy markets. At the same time, Africa contains a large number of minerals, such as platinum, manganese, ruthenium, gold and other rare metals, copper, zinc, iron, diamond, phosphate and other mineral resources, which are rich in reserves and still under development, so there is a large space for future exploitation. Second, Africa has a large population and abundant cheap labor, and labor costs are low here. In recent years, the political environment in Africa is relatively stable, and the government has adopted corresponding policies to promote economic development. Internally, Africa has formulated a development strategy of seeking strength through unity and independent development. It is united internally and less dependent on the outside world. Externally, Africa enjoys a lot of preferential policies. The policy advantages of a series of organizations such as the World Trade Organization have created favourable conditions for Africa's economic development. If African countries learn from the development experience of China and other countries and have the foresight to invest properly in their youth, this demographic advantage would make a big difference on the continent.

Africa is a continent with a relatively backward transportation industry in the world and has not formed a complete transportation system. Most of the transport links run inland from coastal ports and are isolated from each other. Transportation is mainly by road, as well as railway and sea transportation. At present, Africa has more than 1.3 million $\mathrm{km}$ of roads and 78,000 km of railways. Inland waterway navigable mileage of about 52,000 km. [18] Shipping industry plays an important role. The aviation industry is developing rapidly. Africa, with its advantageous geographical location, is an important hub connecting Asia and Africa.

\subsection{Economic cooperation}

There are many cooperative projects between China and Africa. The most important is the ten cooperation plans. China and Africa reached the top ten cooperation program, including the ChinaAfrica cooperation of industrialization, agricultural modernization cooperation plan, infrastructure cooperation plan, financial plan, green development and cooperation, trade and investment facilitation cooperation plan, poverty reduction, human cooperation plan, public health cooperation plan, cultural cooperation plan, peace and security cooperation plan.

According to preliminary statistics, 'top ten cooperation plan' since then, the Chinese enterprises in Africa and under construction projects have been completed, will help Africa to add about 30,000 $\mathrm{km}$ highway mileage, 85 million tons/year of port capacity, the clean water processing capacity of more than 9 million tons/day, nearly 20000 megawatts of electricity capacity and more than 30000 $\mathrm{km}$ of transmission lines, nearly 900,000 jobs will be created for African countries. China has also 
implemented hundreds of projects for African countries in agriculture, poverty reduction, public health, trade and investment facilitation and other fields.

As shown in Figure 3 that China-Africa investment cooperation has developed rapidly in recent years. In 2017, China's direct investment in Africa reached US $\$ 41.1$ billion, nearly 40 times that of 2003. By the end of 2017, China's investment stock in Africa of all kinds exceeded US $\$ 100$ billion, covering almost every African country.

At the same time, investment forms are more diversified. In terms of sectors, China's investment in Africa has gradually expanded, covering construction, mining, manufacturing, science and technology, geological exploration, real estate, finance, wholesale and retail and agriculture. From the way of investment, in addition to sole proprietorship, joint ventures, there are shares, mergers and acquisitions. In recent years, investment in Africa by private enterprises has also grown rapidly and has gradually become a new force of investment in Africa. At present, there are concessional loans, China-Africa Development Fund, China-Africa Industrial Capacity Cooperation Fund, and special Loans for African. The China-Africa Development Fund has invested a total of 4.6 billion US dollars in 91 projects in 36 African countries, which could lead to over 22 billion US dollars of Chinese investment in Africa, covering agriculture, people's livelihood, infrastructure, mineral resources and finance.

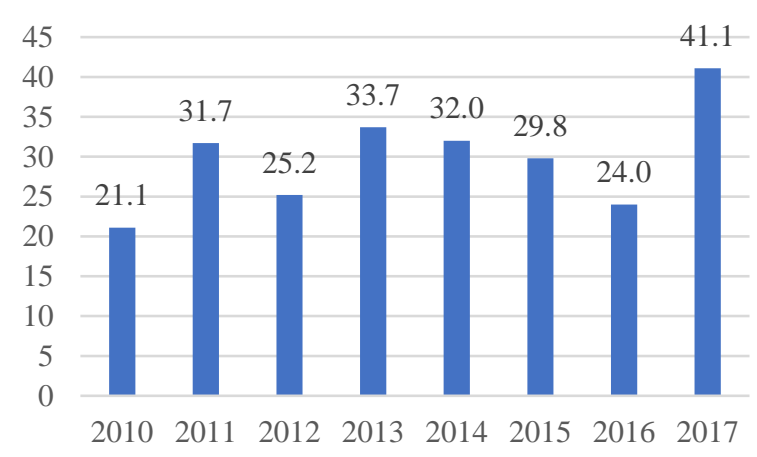

Figure 3. Annual flow of China's investment to Africa (Unit: Hundred Million US Dollars)

According to statistics, Chinese enterprises have also set up about 25 economic and trade cooperation zones in Africa, providing more platforms for Chinese enterprises to invest in Africa. At present, there are more than 400 enterprises in the 25 economic and trade cooperation zones, with a cumulative investment of more than 6 billion US dollars, covering various fields, and an output value of about 18.9 billion US dollars. The tax paid to the host countries has reached 900 million US dollars, and about 41,000 foreign employees have been employed, greatly promoting Africa's industrialization and economic development and creating jobs.[19]

\section{How Does Africa Fit into the Belt and Road Initiative and Implications for Africa?}

\subsection{The Benefits Brought to China by the Belt and Road Initiative}

As for the Belt and Road Initiative, many people still do not understand why China is spending so much money on aid to Africa. To understand this problem, one must first understand the big premise, and that is China's overcapacity. Overcapacity is a condition that occurs when demand for a product is less than the amount of product that a business could potentially supply to the market. When a firm is producing at a lower scale of output than it has been designed for, it creates overcapacity.

Once overcapacity occurs, vicious competition and price war are easy to occur, accompanied by the decline of profits in the real economy, unemployment and bankruptcy, causing a great impact on the social economy. To solve the problem of overcapacity, the Chinese used to build infrastructure, usually railways, roads and infrastructure, commonly known as "the railway infrastructure." That 
would create jobs and reinvigorate consumption. The construction of those I'll always be an end to the construction of infrastructure, when they have no road to build one day. How to deal with those powerful capacities? In this case, there are two methods: One is to change the track for "railway infrastructure", so the "new infrastructure" came into being. It will not only upgrade China's science and technology industry, but also bring happiness to the people and absorb a large amount of excess capacity. The other is to send capacity abroad to avoid overcapacity and to invest in other countries for greater returns later. It happens that most African countries along the Belt and Road are in dire need of infrastructure. Africa has the demand, China has the capacity, and China has absorbed too much capacity in helping Africa build infrastructure, achieving a win-win situation. When the infrastructure of African countries is completed, the economy will grow dramatically. At this time, China can export more goods, such as $3 \mathrm{C}$, white goods, clothing, science and technology products, and bring more economic growth.

\subsection{Benefits of the Belt and Road Initiative to Africa}

The Belt and Road initiative will bring the wave of industrialization that Africa needs. First, the influx of Chinese workers, machinery and infrastructure technology will elevate the overall level of local technology, making the leap from agricultural civilization to industrial civilization. Second, tens of billions of dollars of investment will inevitably hire a large number of local workers and support local enterprises, directly driving the economy into a positive cycle. When the first wave of iron infrastructure hits the ground, locally produced goods will be able to move, and as long as goods move, it means economic growth. From then on, they will gradually prosper and their people will live in prosperity and security. Without China's help, they would have had little chance to industrialize on their own. Therefore, Africa has a very high opinion of the Belt and Road Initiative. So far, China has built more than 1,000 complete projects for Africa. It involves poverty reduction, medical and health care, education and training, logistics and transportation, and infrastructure. China's annual aid to Africa projects amount to more than US $\$ 60$ billion, bringing tangible benefits to the people of recipient countries.

\subsection{Chinese Overseas Commercial Strategy}

After more than 30 years of continuous efforts, China has become the world's second largest economy. Since China joined the World Trade Organization in 2001, the process of China's integration into the world has been accelerating, and it is also confronted with many opportunities and challenges. Based on the world situation, China has developed its own overseas business strategy. Early preliminary planning was based on export-oriented integration into the world market. China takes advantage of its excellent investment environment to actively participate in the division of labor within international products and vigorously absorb foreign direct investment. At the same time, give full play to the advantages of cheap labor to develop processing trade. Globalization has relaxed the rigid constraint of the market on China's economic development, not only directly promoted the growth of China's export trade and economic development, but also made China one of the biggest beneficiaries of economic globalization. China, especially the eastern coastal areas, has become a veritable "world factory".

Since the 2008 U.S. financial crisis, China has recognized that it needs to rebalance with the world economy. The dividends of the first wave of export-oriented globalization, in which low-end factors joined the global value chain in the past, have been overdrawn and cannot be sustained. China's globalization strategy urgently needs transformation and upgrading.

At present, China is implementing a globalization strategy based on domestic demand, both at home and abroad. In addition to stimulating domestic demand and linking with the global market, the Belt and Road initiative initiated by China with the participation of many countries is the top priority of this strategy. In the Belt and Road projects, the market of other countries is used to meet the demand of low-end domestic factors of production, and the domestic market is also used to meet the demand of advanced foreign factors of production. In this process, large domestic manufacturing enterprises 
or Chinese multinational companies build large-scale infrastructure projects according to market demand to form a global supply chain, and then sell their output to the world.

Table 1. 2014-2020 China's Trade with Africa (Unit: Hundred Million US Dollars)

\begin{tabular}{|c|c|c|c|c|c|c|}
\hline Annual & $\begin{array}{c}\text { Exports to } \\
\text { Africa }\end{array}$ & $\begin{array}{r}\text { Year-on- } \\
\text { year growth }\end{array}$ & $\begin{array}{c}\text { Imports to } \\
\text { Africa }\end{array}$ & $\begin{array}{r}\text { Year-on- } \\
\text { year growth }\end{array}$ & $\begin{array}{r}\text { Total } \\
\text { import and } \\
\text { export }\end{array}$ & $\begin{array}{c}\text { Year-on- } \\
\text { year growth }\end{array}$ \\
\hline 2014 & 1062 & $14 \%$ & 1157 & $-2 \%$ & 2219 & $6 \%$ \\
\hline 2015 & 1087 & $2 \%$ & 704 & $-39 \%$ & 1790 & $-19 \%$ \\
\hline 2016 & 923 & $-15 \%$ & 569 & $-19 \%$ & 1492 & $-17 \%$ \\
\hline 2017 & 947 & $3 \%$ & 753 & $32 \%$ & 1700 & $14 \%$ \\
\hline 2018 & 1049 & $11 \%$ & 993 & $32 \%$ & 2042 & $20 \%$ \\
\hline 2019 & 1132 & $7.9 \%$ & 995 & $-3.8 \%$ & 2087 & $2.21 \%$ \\
\hline 2020 & 1142 & $0.9 \%$ & 727 & $-24.1 \%$ & 1870 & $-10.5 \%$ \\
\hline
\end{tabular}

Africa has been a top priority in China's ongoing overseas business strategy. Africa, as one of the underdeveloped regions in the world, has great potential for development. The production capacity of China and Africa is highly complementary, and Africa's development potential will create a huge market. China has the capital and the technology while Africa needs industrialization, capital and employment. Africa is rich in resources, such as crude oil, manganese and copper. But these resources have long been under exploited, and China can trade them at a more reasonable price. China imports more copper and cotton from Africa than it does domestically. Chinese companies' oil field projects in Africa have greatly helped China's energy security. China's import and export trade with Africa has remained stable. As shown in table 1, in 2019, total Sino-Africa trade reached 2,087 hundred million US dollars. In 2020, China's exports to Africa continued to rise despite the impact of COVID19 and the poor global economic development, with the total trade volume reaching 1870 hundred million US dollars.

At the same time, to realize the globalization of the world economy and trade, the African region is the focus. African countries have not kept pace with globalization and have not gained development opportunities from globalization. They have not really entered the track of industrialization. This growing disparity in levels of development is the most fundamental problem facing the world economy. As the overall strength of developing countries increases, the global balance of power changes that developing and developed countries gradually move toward balance. All these aspects require the active participation of African countries. Expanding trade between China and Africa will not only benefit both sides, but also help mobilize forces supporting global free trade to maintain and consolidate the existing global free trade system.

For example, Mombasa-Nairobi Standard Gauge Railway connects Mombasa, the largest seaport in East Africa, and Nairobi, the capital city of Kenya, which is the most expensive project in Kenya since it got independence. This project is not only important to deepen Sino-Africa cooperation, but also is a cornerstone of Chinese overseas commercial strategy. China has advanced high-speed train technology and also has abundant high-speed railways management and operating experience. The whole $480 \mathrm{kms}$ railway fully adopted China's technology and standard, even the stewards were sent to China to receive training. Here we can see China's ambition to export not only the commodities to Africa but also the rules and standards, which make Africa rely on China much deeper. The Mombasa-Nairobi Standard Gauge Railway is just the first step of China to expand African railways market, in the future, China plans to connect Tanzania, Uganda, Rwanda, Burundi, South Sudan, Ethiopia, and some other east and central African countries, which may become a crucial transportation network that links the coastal area with central inland areas. 


\section{Challenges}

\subsection{Political Risk}

The biggest challenge for the BRI is the unstable domestic political situation of several African countries. The border disputes, religious and racial conflicts are ceaseless in the African continent. Over 2019 and 2020, East Africa had nearly 42000 mortalities because of armed conflicts. Plus, the threat of terrorism in Africa cannot be ignored, in the Horn of Africa (Somalia, Ethiopia and Kenya), the terrorist activities related to the Islamic Jihad movement had never ended for years, what is worse is the Taliban successfully took Afghanistan regime recently, the terrorism began to rise in many regions in the world including the Horn of Africa. Security is always one of the priorities for a company investment, the turbulent political situation in several African countries will be a big problem for the further development of the BRI.

\subsection{France's Reaction}

Most of the African countries do not have an effective and reliable financial system, for example, 14 countries in the west and central still use CFA Franc, most of them are former French colonies. Even after they got independence, they continued to use CFA Franc for stabilizing their currency and hoped to have a strong monetary system. As a consequence, France still holds $50 \%$ of the foreign exchange reserves of CFA, which has a strong control of these African countries' monetary systems. Thus, France has a lot of existing benefits in France and it will not let China easily take its benefit in Africa. As a challenger, China not only needs to consider how to do business and investment in African countries but also should know how to reach cooperation or compromise with France.

\subsection{Others}

China and Africa have different cultural backgrounds, Chinese workers and employees are hard to integrate with the local communities and the conflicts between local and Chinese workers are inevitable. The company should consider how to seek a harmonious relationship between them. Plus, the environmental risk also needs to be taken into consideration, because most of the projects in BRI are about infrastructure, they definitely will impact the environment. China had figured out many methods to mitigate the effect, for example, Mombasa-Nairobi Standard Gauge Railway was located in the animal migration route, and the engineers cooperated with the local animal protection organizations to design the railway. There are 14 wildlife corridors and 79 bridges for wild animals to pass through. The BRI in Africa is a big and sophisticated project, it will face a lot of challenges. What is important is whether this project can bring a sense of well-being to the people.

\section{Conclusion}

This paper explores the background of the Belt and Road Initiative and Sino-Africa cooperation. Also, it studies the Africa's current situation of infrastructure, Africa's comparative advantages and the situation of Sino-Africa cooperation, and draws the following conclusions: the current situation of African infrastructure is relatively poor, but Africa is rich in land resources, mineral resources and labor resources. In recent years, Sino-Africa investment cooperation has grown rapidly on a large scale and in a wide range. If African countries can learn from the development experience of China and invest appropriately in their young people with foresight, such a demographic advantage would make a big difference on the continent. In addition, this study analyses the benefits brought to China and Africa through the Belt and Road Initiative and China's overseas development strategy, which indicates that Africa has always been the top priority of China's current overseas business strategy. The Belt and Road cooperation can bring win-win results to the two countries. China can consume excess production capacity, and African countries can complete industrialization with China's help, so as to promote commodity circulation and economic development. Afterwards, the political risk in Africa and potential challenges for China's involvement are analyzed. 


\section{References}

[1] Julia Breuer (2017). Two Belt One Road? The role of Africa in China's Belt and Road initiative.

[2] Olayiwola Abegunrin, Charity Manyeruke (2019). China's One Belt One Road Initiative in Africa.

[3] Huiping Chen (2016) China's 'One Belt, One Road' initiative and its implications for Sino-African investment relations, Transnational Corporations Review, 8: 3, 178 - 182.

[4] Deich T. (2020). Africa's Place in the Chinese Initiative "One Belt, One Road". Mirovaia ekonomika i mezhdunarodnye otnosheniya 64 (2), pp.118 - 127.

[5] Mukwaya, R., \& Mold, A. (2018). Modelling the economic impact of the China Belt and Road Initiative on countries in Eastern Africa. (Presented at the 21st Annual Conference on Global Economic Analysis, Cartagena, Colombia). Purdue University, West Lafayette, IN: Global Trade Analysis Project (GTAP).

[6] Githaiga, N. M., \& Bing, W. (2019). Belt and Road Initiative in Africa: The Impact of Standard Gauge Railway in Kenya. China Report, 55 (3), $219-240$.

[7] Calderón, César. 2009. Infrastructure and Growth in Africa. Policy Research working paper; no. WPS 4914. World Bank. (C) World Bank.

[8] Mwatela, Z. (2016). Africa in China's One Belt One Road: A Critical Analysis. IOSR Journal of Humanities and Social Sciences.

[9] Micheal, M \& Hodan, O (2017). Sustaining China-Africa relations: Slotting Africa into China's One Belt, One Road initiative makes economic sense.

[10] Zhou, B. Q. (2019). Cooperation between China and Africa under the One Belt One Road Initiative: China's Benefits and Problems. Chinese Studies, 8, 27 - 41.

[11] DAVID DOLLAR (2019) Understanding China's Belt and Road Infrastructure Projects in Africa.

[12] "Calderon, Cesar; Cantu, Catalina; Chuhan-Pole, Punam. 2018. Infrastructure Development in SubSaharan Africa: A Scorecard. Policy Research Working Paper; No. 8425. World Bank, Washington, DC. (C) World Bank.

[13] "Teravaninthorn, Supee; Raballand, Gaël. 2009. Transport Prices and Costs in Africa: A Review of the International Corridors. Directions in Development; Infrastructure. Washington, DC: World Bank. () World Bank.

[14] Information from wikipedia https://en.wikipedia.org/wiki/Africa

[15] Information from wikipedia https://en.wikipedia.org/wiki/List_of_countries_by_rail_transport_network_size

[16] IEA (2019), Africa Energy Outlook 2019, IEA, Paris https://www.iea.org/reports/africa-energy-outlook2019.

[17] Information from International Telecommunication Union https://www.itu.int/pub/D-TDC-WTDC-2014

[18] Information from wikipedia https://en.wikipedia.org/wiki/Trans-African_Highway_network.

[19] Information from the Chinese Government Website http://www.gov.cn/xinwen/201808/29/content_5317272.htm 